\title{
Membangun Jiwa Wirausaha Anggota Aisyiyah Sinduadi Tengah, Mlati, Sleman Melalui Usaha Makanan Dan Minuman Halalan Thoyyiban
}

\author{
Pujastuti Sulistyaning Dyah*1, Lestari Rahayu² \\ Prodi Agribisnis, Fakultas Pertanian, Universitas Muhammadiyah Yogyakarta, Jl. Brawijaya, Tamantirto, Kasihan, Bantul, D.I. Yogyakarta \\ *1Email: pujastuti@umy.ac.id \\ DOI: $10.18196 / p p m .32 .218$
}

\begin{abstract}
Abstrak
Di tengah maraknya penyebaran virus Corona (Covid-19), tanaman rimpang menjadi ramuan yang banyak diandalkan masyarakat. Minuman jahe merupakan salah satu minuman yang halal dan thoyyib karena selain bermanfaat sebagai bumbu, jahe juga memberi manfaat bagi Kesehatan, yakni memberikan efek antioksidan, anti peradangan, serta memberi perlindungan yang maksimal terhadap tubuh, termasuk perlindungan dari virus Corona. Selain minuman jahe, materi pengabdian ini juga melatih pembuatan bubuk jahe (bon cabai). Dampak dari pandemi Covid-19 adalah produk cabai sebagai salah satu komoditas pertanian melimpah dan tidak terserap oleh pasar sehingga sangat merugikan petani. Dengan diolahnya cabai menjadi bentuk bubuk, hal ini akan menyelamatkan produk cabai dari kerusakan. Mitra dalam Program Pengabdian Masyarakat Berbasis Persyarikatan Muhammadiyah (PPM MUH) adalah Aisyiyah Ranting Sinduadi Tengan, Mlati, Sleman. Tingkat pendapatan rumah tangga anggota Aisyiyah sebagian besar masih rendah. Pimpinan Cabang Aisyiyah Mlati sebagai mitra berencana memberdayakan ibu-ibu anggota Aisyiyah untuk membentuk kelompok usaha mandiri yang bisa membantu menopang keuangan keluarga. Target luaran yang ingin dicapai adalah memotivasi kelompok mitra agar tumbuh jiwa kewirausahaannya dengan melakukan usaha makanan dan minuman di masa pandemi ini.
\end{abstract}

Keywords: Aisyiyah, halal thoyyib, bubuk cabai, bubukjahe.

\section{Pendahuluan}

Makanan dan minuman halalan thayyiban merupakan kebutuhan seorang muslim, bahkan manusia pada umumnya. Hal ini disebabkan organ-organ tubuh akan sehat dan afiat jika diisi dengan konsumsi makanan halalan thayyiban. Sebaliknya, badan akan mudah rusak dan mudah sakit manakala diisi dengan bahan-bahan yang haram. Mengonsumsi makanan halalan thayyiban juga merupakan tanda kesyukuran seorang hamba kepada Allah Sang Pencipta yang telah memberikan manusia berbagai sumber makanan dan minuman yang tidak terhingga. Manusia tinggal memilih dan memilah yang layak untuk dikonsumsi dan yang tidak patut dikonsumsi.

Semua bahan makanan dihasilkan dari sektor pertanian. Bahan hasil pertanian pada umumnya memiliki nutrisi yang memungkinkan dapat menjadi tempat bertumbuhnya mikroba dan serangga. Oleh karen aitu, diperlukan teknik penanganan yang bagus sebagai tindakan pencegahan (Yuniarto and Lastriyanto, 2019).

Dampak dari pandemi Covid-19 yang multidimensi menyebabkan banyak kesulitan dan hambatan. Di sektor ekonomi tampak sekali dampaknya, tidak terkecuali di bidang pertanian. Pemasaran produk pertanian terkendala dengan terbatasnya mobilitas transportasi, ditambah lagi sifat produk pertanian yang pada umumnya mudah rusak, tidak tahan lama. Salah satu produk pertanian yang terkena dampak tersebut adalah cabai. Melimpahnya cabai di pasaran dan mengalami kesulitan penjualan menyebabkan harga cabai sangat rendah. Kondisi ini sangat merugikan petani cabai saat itu. Harga cabai dalam keadaan normal saat itu bisa mencapai Rp30.000,00/kg. Dengan kondisi pandemi seperti ini, harga cabai berada di titik terendah selama ini, yaitu Rp6000,00/kg. Di tingkat petani, penanganan pascapanen produk cabai masih sederhana sehingga tingkat kerusakannya cukup tinggi, yakni mencapai 40\%. Oleh karena itu, penanganan pascapanen cabai merah perlu diperbaiki, mulai dari panen, pengemasan, pengangkutan, hingga penyimpanan. Hal ini dilakukan untuk meningkatkan daya simpan, nilai 
jual produk, dan pendapatan petani (Taufik, 2016). Salah satu solusi dalam menangani masalah kerusakan produk cabai adalah dengan mengubah bentuk cabai menjadi bubuk cabai, yaitu dengan cara dikeringkan dan digiling. Dengan diolahnya cabai menjadi bentuk bubuk akan memudahkan dalam penggunaan selanjutnya sebagai produk siap pakai. Manfaat cabai sebagai komponen makanan mempunyai kandungan banyak gizi, di antaranya kalori, protein, lemak, karbohidrat, kalsium, dan vitamin C. Rasa cabai yang pedas disebabkan oleh kandungan capsaicin yang ada di dalamnya (Sisca et al., 2010).

Selain cabai, jahe juga memiliki manfaat dalam bidang kesehatan. Zat aktif berupa zingeron dan senyawa antioksidan lain yang terkandung dalam jahe dapat digunakan untuk bumbu masak, pemberi aroma dan rasa pada makanan, seperti roti, kue, biskuit, kembang gula dan berbagai minuman. Selain itu, jahe juga digunakan dalam industri obat, minyak wangi, dan jamu tradisional (Aziz, 2018).

Di tengah maraknya penyebaran virus Corona (Covid-19), tanaman rimpang menjadi ramuan yang banyak diandalkan masyarakat, termasuk tanaman rimpang jahe, kunyit, temulawak, kencur, atau lengkuas. Tanaman rimpang tersebut bermanfaat sebagai bumbu masakan yang digunakan sehari-hari. Khususnya jahe, komoditas ini lazim dibuat sebagai minuman yang berguna untuk menghangatkan tubuh, menambah daya tahan tubuh agar imun tubuh jadi lebih baik. Minuman jahe sangat diminati masyarakat di masa pandemi Covid-19, yakni sebagai asupan gizi untuk menambah imunitas tubuh terhadap penyakit. Minuman jahe ini dibuat dari rimpang jahe yang diolah menjadi bubuk jahe agar menjadi praktis. Kelebihan lain dari serbuk minuman instan ialah dapat disimpan dalam jangka waktu yang lama karena telah melalui proses pengawetan alamiah berupa kristalisasi dengan gula melalui pemanasan.Selanjutnya, ditambahkan gula pasir sehingga terbentuk bubuk kristal (Susanty and Yulendra, 2018). Bahan dasar jahe ini mudah diperoleh di pasaran sepanjang tahun.

Proses pembuatan kedua komoditas ini sederhana dan tidak memerlukan biaya yang banyak, tetapi belum banyak dilakukan setingkat home industri, terutama di wilayah Sinduadi. Dengan diperkenalkannya pelatihan produk-produk pertanian seperti ini diharapkan dapat menjadi pioner untuk masyarakat di sekitarnya.

Sasaran yang menjadi objek pengabdian ini adalah ibu-ibu anggota Aisyiyah di Ranting Sinduadi Tengah, Kecamatan Mlati, Kabupaten Sleman. Diharapkan hasil pelatihan ini dapat menjadikan peluang untuk menambah penghasilan keluarga yang sebagian besar anggota Aisyiyah ini hanya sebagai ibu rumah tangga dan tidak mempunyai pekerjaan.

Tujuan pengabdian ini adalah melatih objek sasaran membuat produk olahan bubuk cabai dan bubuk jahe sebagai sarana untuk menumbuhkan jiwa kewirausahaan di lingkungannya. Kegiatan ini juga bermitra dengan beberapa mahasiswa UMY yang sedang melakukan kegiatan magang. Mereka belajar dan memberi pelatihan kepada objek sasaran sebagai kegiatan usaha mandiri.

\section{Metode Pelaksanaan}

Pelaksanaan kegiatan pengabdian ini dimulai dengan koordinasi bersama Ketua Aisyiyah Ranting Sinduadi Tengah dan mahasiswa yang akan melakukan kegiatan magang. Kegiatan pengabdian ini menggunakan metode penyuluhan dan pelatihan. Pelatihan pembuatan bubuk cabai dan bubuk jahe dilakukan dengan mengundang pelatih yang sudah profesional untuk belajar bersama. Kegiatan dilakukan di Laboratorium Agribisnis UMY. Tahap berikutnya adalah melatih objek sasaran, yaitu anggota Aisyiyah sebanyak dua tahap.Pelatihan ini dilakukan di rumah Ketua Aisyiyah Ranting Sinduadi Tengah. Karena jumlah peserta pelatihan cukup banyak, agar sesuai prosedur protokol kesehatan, pelatihan dilakukan bertahap supaya bisa menjaga jarak. Peserta pelatihan juga harus menggunakan perlengkapan masker dan face shield (tutup muka). Demikian juga pada saat pelatihan di laboratorium. 


\section{Hasil dan Pembahasan}

Bubuk cabai dan bubuk jahe merupakan salah satu bentuk penanganan olahan produk sebagai solusi dalam mengatasi sifat karakreristik produk pertanian, dalam hal ini cabai dan jahe, yang mudah rusak. Bentuk pengawetan produk cabai dan jahe ini adalah pengeringan dengan cara penjemuran/pemanasan untuk cabai dan pengkristalan untuk jahe. Dengan proses tersebut dapat menghambat proses pertumbuhan mikroba pada produk.

1. Pelatihan Pembuatan Bubuk Cabai.

Kegiatan pengabdian ini diawali dengan pelatihan awal pembuatan bubuk cabai dengan mempelajari materi dari youtube bersama mahasiswa magang. Ada empat tahap dalam pembuatan bubuk cabai, yaitu pengeringan, penggilingan, pengayakan, dan pengemasan. Pengeringan dilakukan dengan penjemuran selama 5 hari sampai cabai benar-benar kering. Tahap berikutnya adalah menggiling. Cabai kering tersebut digiling dengan chooper atau blender dan ditambah bumbu-bumbu agar enak rasanya. Agar cabai seragam teksturnya, dilakukan pengayakan dengan menggunakan saringan. Tahap terakhir adalah pengemasan.

2. Pelatihan Pembuatan Bubuk Jahe.

Kegiatan pembuatan bubuk jahe diawali dengan prapelatihan, yaitu dengan mengundang tenaga profesional yang sudah terlatih membuat bubuk jahe. Kegiatan ini dilakukan di Laboratorium Agribisnis UMY. Tahap pertama kegiatan ini meliputi pencucian, pengupasan rimpang jahe dan bahan penyerta. Tahap kedua, menggiling rimpang jahe dan bahan penyerta berupa kunyit, temu lawak, cengkeh dengan menggunakan chooper atau blender dan ditambah sejumlah air. Tahap ketiga adalah penyaringan larutan dengan menggunakan saringan, kemudian didiamkan agar terpisah antara larutan dengan endapannya. Tahap keempat, memanaskan larutan dengan menambahkan gula pasir dengan menggunakan kompor selama 2 jam dan dilakukan pengadukan sampai larutan mulai mengental dan mengkristal. Tahap kelima adalah pengayakan dengan menggunakan saringan. Tahap keenam adalah pengemasan dan pelabelan.

Hasil pembelajaran kemudian dipraktikkan bersama ibu-ibu anggota Aisyiyah Ranting Sinduadi Tengah, Kecamatan Mlati, Kabupaten Sleman dalam 2 tahap pelatihan. Tahap pertama dilakukan di rumah salah satu anggota Aisyiyah dan tahap kedua dilakukan di rumah Ibu Ketua Aisyiyah tersebut.

Karena pelaksanaan kegiatan pengabdian ini dilakukan pada saat pandemi Covid-19, sesuai dengan prosedur prokokol kesehatan, pelatihan menggunakan masker, memakai face shield, mencuci tangan, dan tidak berkerumun. Strategi pelatihan dilakukan secara bertahap.

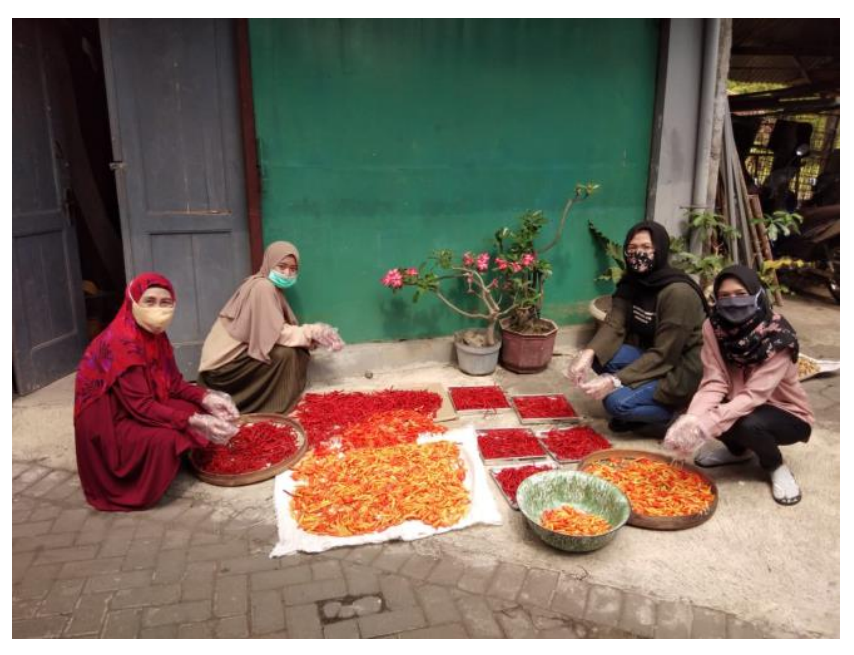

Gambar 1. Penjemuran Cabai 


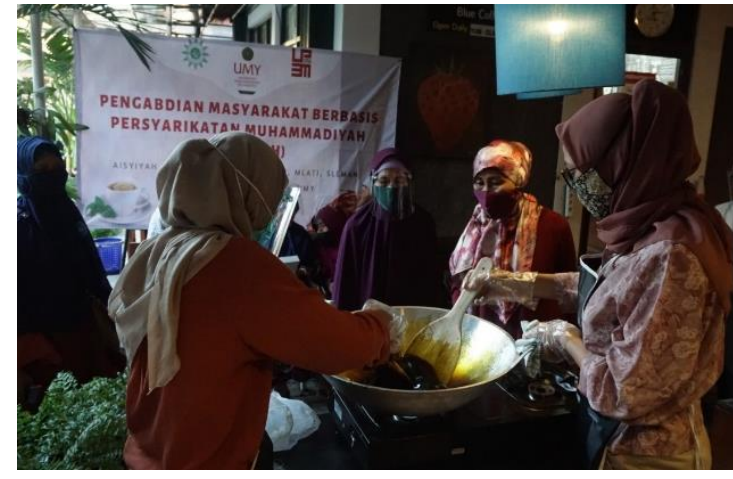

(a)

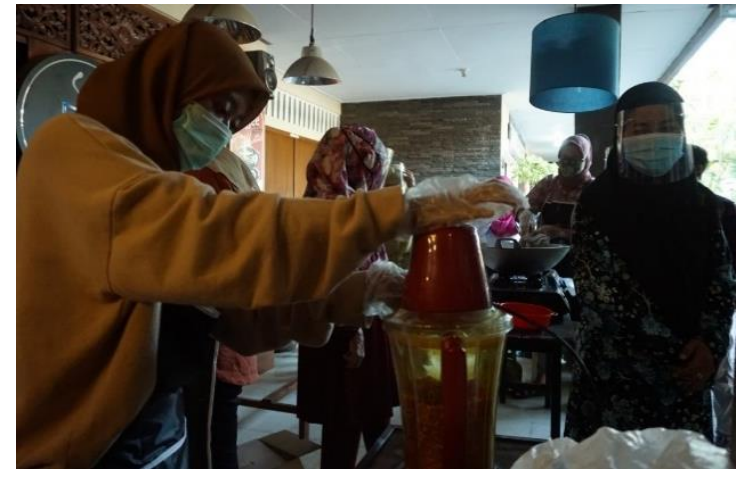

(b)

Gambar 2. (a) Pelatihan Pembuatan Bubuk Jahe, (b) Pelatihan Pembuatan Bubuk Cabai

Kegiatan pengabdian berjalan lancar sesuai dengan rencana. Tanggapan dari peserta sangat baik dan penuh semangat. Hal ini ditunjukkan dengan antusiasnya peserta pelatihan mengikuti proses tahapan yang diberikan dari awal sampai akhir dan banyak pertanyaan yang diajukan peserta pelatihan.

Kegiatan pengabdian diakhiri dengan pengisian kuesioner tentang respons dari kegiatan ini kepada peserta pelatihan. Selanjutnya, penyerahan barang yang dihibahkan kepada kelompok peserta pelatihan yang diterima oleh Ibu Ketua Ranting Aisyiyah Sinduadi, Mlati, Sleman. Barang tersebut berupa peralatan pembuatan cabe/jahe seperti chooper/blender, wajan, kompor, sheeler, dan oven.

Adanya pelatihan pembuatan bubuk cabai dan bubuk jahe ini selain melatih ketrampilan, juga berguna untuk memanfaatkan produk pertanian yang sedang berlimpah agar lebih tahan lama. Harapannya, pelatihan ini dapat menumbuhkan jiwa kewirausahaan bagi anggota Aisyiyah di Ranting Sinduadi Tengah, Mlati, Sleman.

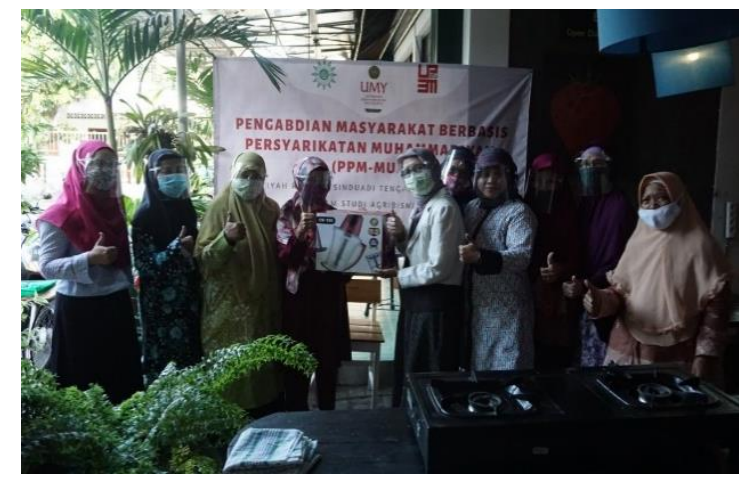

(a)

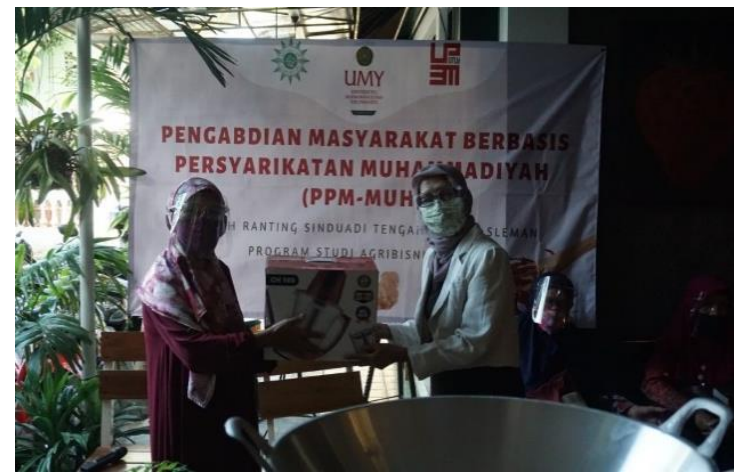

(b)

Gambar 3. (a) Foto bersama mitra, (b) Foto serah terima barang

\section{Simpulan}

Bentuk pengawetan produk cabai dan jahe dalam bentuk bubuk sebagai solusi untuk menghindarkan produk dari kerusakan. Selain menjadi lebih praktis dan enak cita rasanya, bubuk cabai dan jahe dapat menjadi makanan dan minuman yang halal dan thoyyiban. Minuman jahe cocok dikonsumsi di masa pandemi ini sebagai nutrisi yang dapat menambah daya tahan tubuh terhadap penyakit. Melalui kegiatan pengabdian ini, pelatihan membuat 
bubuk cabai dan jahe diharapkan dapat menumbuhkan jiwa kewirausahaan bagi anggota Aisyiyah yang ada di Sinduadi Tengah, Mlati, Sleman.

\section{Ucapan Terima Kasih}

Ucapan terima kasih kami ucapkan kepada LP3M UMY yang telah memberikan dana pada kegiatan pengabdian ini melalui program Pembelajaran Pemberdayaan Masyarakat (PPM). Rasa terima kasih juga kami sampaikan kepada Ibu Ir. Dwi Setyowati selaku Ketua Aisyiyah Ranting Sinduadi Tengah yang telah memberi kesempatan kepada tim pengabdian untuk melaksanakan kegiatan pengabdian ini di wilayahnya.

\section{Daftar Pustaka}

Aziz, Muhammad. "Pemberdayaan Ibu-Ibu Rumah Tangga Dengan Keterampilan Membuat Serbuk Jahe Instan." Jurnal Pemberdayaan: Publikasi Hasil Pengabdian Kepada Masyarakat, vol. 1, no. 2, 2018, p. 259, doi:10.12928/jp.v1i2.349.

Sisca, Sherly, et al. Budidaya Dan Pascapanen Cabai Merah. no. 01, 2010.

Susanty, Sri, and Lalu Yulendra. Panduan Proses Pengolahan Jahe Menjadi Jahe Serbuk Instan. no. April, 2018, pp. 1-37.

Taufik, Muh. "Analisis Pendapatan Usaha Tani Dan Penanganan Pascapanen Cabai Merah." Analisis Pendapatan Usaha Tani Dan Penanganan Pascapanen Cabai Merah, vol. 30, no. 2, 2016, pp. 66-72, doi:10.21082/jp3.v30n2.2011.p66-72.

Yuniarto, Kurniawan, and Anang Lastriyanto. “Teknik Pengolahan Hasil Pertanian.” Cetakan 1, Plantaxia. Edisi Pertama, 2019. 